\title{
FAKTOR YANG MEMPENGARUHI KELENGKAPAN PENGUNGKAPAN LAPORAN KEUANGAN PADA PERUSAHAAN MANUFAKTUR YANG TERDAFTAR DI BEI
}

\author{
Rofika ${ }^{1}$ dan Mustika Debby Apsari \\ Dosen Fakultas Ekonomi Universitas Riau
}

\begin{abstract}
ABSTRAK
Bapepam melalui Surat Keputusan Bapepam No. 06/PM/2000 tanggal 13 Maret 2000 tentang Pedoman penyajian Laporan Keuangan mensyaratkan elemen-elemen yang seharusnya diungkapkan dalam laporan keuangan perusahaan-perusahaan publik di Indonesia. Penelitian ini bertujuan menguji faktor-faktor yang mempengaruhi kelengkapan pengungkapan laporan keuangan perusahaan. Variabel independen yang digunakan adalah basis perusahaan, ukuran perusahaan, profitabilitas, leverage, proporsi kepemilikan saham publik, reputasi KAP dan likuiditas. Sampel penelitian dengan menggunakan metode purposive sampling diperoleh sebanyak 81 perusahaan manufaktur yang terdaftar di Bursa Efek Indonesia. . Hasil analisa regresi berganda pada $\alpha=5 \%$ menujukkan bahwa ukuran perusahaan dan leverage memiliki pengaruh yang signifikan terhadap kelengkapan pengungkapan laporan keuangan. Sedangkan variabel yang lain tidak memiliki pengaruh yang signifikan.
\end{abstract}

Kata kunci:pengungkapan, laporan keuangan, basis perusahaan.

\section{PENDAHULUAN}

Berubahnya kondisi lingkungan ekonomi banyak berpengaruh pada dunia usaha. Untuk dapat lebih bersaing, perusahaan dihadapkan pada kondisi untuk dapat lebih transparan dalam mengungkapkan informasi perusahaannya, sehingga akan lebih membantu para pengambil keputusan dalam mengantisipasi kondisi yang semakin berubah.

Keterbukaan perusahaan dapat berupa penyampaian informasi perusahaan yang tercermin dalam laporan keuangan secara berkualitas bagi para investor. Informasi yang disampaikan oleh manajemen perusahaan dijadikan sebagai alat analisis dan pengwasan terhadap kinerja manajemen perusahaan. Sementara bagi manajemen, keterbukaan informasi dimaksudkan untuk menunjukkan keseriusan manajemen dalam mengelola perusahaan secara profesional sehingga dapat mempengaruhi para investor dalam pengambilan keputusan.

Di Indonesia yang menjadi otoritas pengungkapan wajib adalah Bapepam. Setiap perusahaan publik diwajibkan membuat laporan keuangan yang diaudit oleh akuntan publik independen sebagai sarana pertanggungjawaban, terutama kepada pemilik modal. Bapepam melalui Surat Keputusan Bapepam No. 06/PM/2000 tanggal 13 Maret 2000 tentang Pedoman penyajian Laporan Keuangan mensyaratkan elemen-elemen yang seharusnya diungkapkan dalam laporan keuangan perusahaan-perusahaan publik di 
Vol 6, No 2, Oktober 2011: 99 - 109

Indonesia. Kemudian untuk pedoman penyajian dan pengungkapan laporan keuangan perusahaan publik industri manufaktur diatur melalui Surat Edaran Ketua Bapepam No. SE-02/PM/2002 tanggal 27 Desember 2002. Dalam Surat Edaran tersebut total item pengungkapan wajib oleh perusahaan manufaktur adalah 128 item.

Pengungkapan laporan keuangan merupakan suatu hal yang harus dilakukan oleh perusahaan dalam penyusunan laporan keuangan. Secara konseptual, pengungkapan merupakan bagian integral dari pelaporan keuangan. Secara teknis, Pengungkapan merupakan langkah akhir dalam proses akuntansi yaitu penyajian informasi dalam bentuk seperangkat penuh statement keuangan.

Untuk mengukur kelengkapan pengungkapan laporan keuangan dapat dinyatakan dalam Indeks Kelengkapan Pengungkapan, dimana perhitungan indeks kelengkapan pengungkapan dilakukan sebagai berikut: 1) memberi skor untuk setiap item pengungkapan secara dikotomi, dimana jika suatu item diungkapkan diberi nilai satu dan jika tidak diungkapkan akan diberi nilai nol: 2) skor yang diperoleh setiap perusahaan dijumlahkan untuk mendapatkan skor total; 3) menghitung Indeks kelengkapan pengungkapan dengan cara membagi total skor yang diperoleh dengan total skor yang diharapkan dapat diperoleh oleh perusahaan.

Semakin banyak butir yang diungkapkan oleh perusahaan, semakin banyak pula angka indeks yang diperoleh perusahaan tersebut. Perusahaan dengan angka indeks yang lebih tinggi menunjukkan bahwa perusahaan tersebut melakukan praktek pengungkapan secara lebih komprehensif dibanding perusahaan lain.

Faktor yang diduga mempengaruhi kelengkapan pengungkapan laporan keuangan sebuah perusahaan adalah: basis perusahaan, ukuran perusahaan, profitabilitas, leverage, proporsi kepemilikan saham publik, reputasi KAP, dan likuiditas.

Basis perusahaan adalah tingkat kepemilikan saham, dimana dibedakan menjadi dua, yaitu berbasis asing dan domestik. Perusahaan dengan basis asing akan memberikan pengungkapan yang lebih luas dibandingkan perusahaan domestik. Alasannya, pertama,perusahaan yang berbasis asing mendapatkan pelatihan yang lebih baik, seperti dalam bidang akuntansi, dari perusahaan induknya diluar negeri. Kedua, Perusahaan yang berbasis asing mungkin mempunyai sistem informasi manajemen yang lebih efisien untuk memenuhi kebutuhan induknya. Dan terakhir, kemungkinan terdapat permintaan informasi yang lebih besar kepada perusahaan berbasis asing dari pelanggan, pemasok, analis, dan masyarakat pada umumnya.

Perusahaan yang berbasis asing dianggap mempunyai teknologi yang cukup, sehingga mendukung terciptanya sistem informasi manajemen yang lebih efisien, akibatnya lebih mudah memberikan akses kedalam sistem pengendalian intern dan kebutuhan informasi bagi perusahaan induk atau dengan kata lain semakin banyak tingkat kepemilikan saham oleh pihak asing maka semakin luas tingkat kelengkapan pengungkapannya. 
Faktor yang Mempengaruhi Kelengkapan Pengungkapan Laporan Keuangan pada Perusahaan Manufaktur yang Terdaftar di BEI (Rofika dan Mustika Debby Apsari)

Farichah (2009) telah membuktikan bahwa basis perusahaan berpengaruh positif dan signifikan dengan tingkat kelengkapan pengungkapan informasi pada laporan keuangan. Namun berbeda dengan penelitian Amalia (2005) dalam penelitiannya menunjukkan bahwa tidak terdapat pengaruh antara basis perusahaan terhadap luas pengungkapan sukarela dalam laporan tahunan.

Ukuran perusahaan merupakan besar kecilnya perusahaan yang dapat dilihat melalui jumlah aktiva secara keseluruhan yang dimiliki oleh perusahaan. Perusahaan yang berukuran lebih besar cenderung memiliki public demand akan informasi yang lebih tinggi dibanding dengan perusahaan yang berukuran lebih kecil. Selain itu, laporan keuangan yang dipublikasikan perusahaan yang berukuran besar lebih bersifat transparan. Transparan akan memperkecil timbulnya asimetri informasi. Sehingga, perusahaan akan mengungkapkan lebih banyak informasi. Ukuran perusahaan terbukti mempengaruhikelengkapan pengungkapan laporan keuangan seperti pada penelitian Irawan (2006), Noviani (2006) dan Almilia dan Retrinasari (2007)

Profitabilitas merupakan faktor yang membuat manajemen menjadi bebas dan fleksibel untuk mengungkapkan laporan keuangan tahunan kepada pemegang saham (Anggraini, 2006 dalam Marulitua, 2009). Pengungkapan yang lebih luas akan terjadi pada perusahaan yang mempunyai profitabilitas yang tinggi. Hal tersebut disebabkan manajemen perusahaan ingin meyakinkan para stakeholders bahwa perusahaan dalam posisi persaingan yang kuat dan kinerja perusahaan yang bagus.

Semakin tingginya rasio profitabilitas perusahaan, menunjukkan semakin tingginya kemampuan perusahaan dalam memperoleh laba dan semakin baik kinerja perusahaannya. Dengan laba yang tinggi perusahaan memiliki cukup dana untuk mengumpulkan, mengelompokkan dan mengelola informasi menjadi lebih bermanfaat serta dapat menyajikan pengungkapan yang lebih komprehensif. Oleh karena itu, perusahaan dengan profitabilitas yang tinggi akan lebih berani mengungkapkan laporan. Dengan demikian semakin tinggi profitabilitas perusahaan maka akan semakin tinggi kelengkapan pengungkapan laporan keuangan.

Simanjuntak dan Widiastuti (2004), menunjukkan bahwa profitabilitas berpengaruh positif terhadap kelengkapan pengungkapan laporan keuangan pada industri manufaktur. Semakin tinggi profitabilitas maka semakin tinggi pula tingkat pengungkapan suatu perusahaan. Namun, Meiyusti (2009) dalam penelitiannya menemukan bukti bahwa terdapat pengaruh negatif antara profitabilitas terhadap tingkat pengungkapan laporan keuangan tahunan.

Leverage merupakan kemampuan perusahaan untuk menggunakan aktiva atau dana yang mempunyai beban tetap (utang) secara efektif sehingga dapat memperoleh tingkat 
Vol 6, No 2, Oktober 2011: 99 - 109

penghasilan yang optimal Meiyusti (2009). Semakin tinggi leverage suatu perusahaan, semakin luas pengungkapan yang dilakukan oleh perusahaan karena semakin besarnya kewajiban perusahaan untuk memenuhi kebutuhan informasi bagi kreditur jangka panjang. Hertanti (2005) dalam penelitiannya menunjukkan bahwa rasio leverage mempunyai pengaruh yang signifikan terhadap kelengkapan pengungkapan laporan keuangan. Hal ini tidak sesuai dengan penelitian Meiyusti (2009) bahwa tingkat leverage tidak berpengaruh signifikan terhadap tingkat pengungkapan laporan keuangan.

Proporsi kepemilikan saham publik juga dapat dijadikan sebagai variabel pengukur dalam luas pengungkapan. Irawan (2004) dan Meiyusti (2009) melakukan penelitian proporsi kepemilikan saham publik yang diukur dengan persentase kepemilikan saham yang dimiliki oleh publik dengan saham yang dimiliki oleh perusahaan berpengaruh terhadap tingkat pengungkapan laporan keuangan. Berbeda dengan penelitian Yuliansyah (2007) menyatakan bahwa tidak terdapat hubungan yang signifikan antara proporsi kepemilikan saham publik dengan luas pengungkapan.

Reputasi kantor akuntan publik (KAP) mempengaruhi tingkat pengungkapan. Reputasi KAP mencerminkan kualitas audit, karena KAP yang bereputasi baik mempunyai komitmen lebih besar untuk mempertahankan kualitas auditnya sehingga laporan keuangan yang sudah diperiksa memberikan keyakinan lebih besar kepada investor akan kondisi going concern perusahaan. Perusahaan yang diaudit oleh KAP yang berkualitas dan bereputasi baik mempunyai tingkat survive yang lebih tinggi. KAP yang baik kualitasnya berpengaruh terhadap tingkat pengungkapan laporan tahunan. Penelitian Meiyusti (2009) membuktikan bahwa Kantor Akuntan Publik mempengaruhi tingkat pengungkapan laporan keuangan. Namun, berbeda dengan penelitian Dwiningsinh (2009) yang menyatakan bahwa Kantor Akuntan Publik tidak berpengaruh terhadap transparansi informasi pada laporan keuangan.

Likuiditas suatu usaha bisnis didefinisikan sebagai kemampuan perusahaan untuk memenuhi kewajiban yang sudah jatuh tempo. Kesehatan suatu perusahaan yang dicerminkan dengan tingginya rasio likuiditas (diukur dengan current ratio) diharapkan berhubungan dengan luasnya tingkat pengungkapan. Hal ini didasari dari adanya pengharapan bahwa secara finansial perusahaan yang kuat akan lebih mengungkapkan informasi dari pada perusahaan yang lemah. Meiyusti (2009) menyatakan bahwa rasio likuiditas berpengaruh terhadap tingkat pengungkapan laporan keuangan tahunan. Hal ini berbeda dengan penelitian Handoko (2006) yang menyatakan bahwa tingkat likuiditas tidak mempunyai pengaruh yang signifikan terhadap luas pengungkapan yang dilakukan perusahaan publik dalam laporan tahunannya.

Penelitian ini bertujuan mengetahui faktor-faktor yang mempengaruhi kelengkapan pengungkapan laporan keuagan perusahan manufaktur di Bursa Efek Indonesia. Faktorfaktor yang digunakan adalah: basis perusahaan, ukuran perusahaan, profitabilitas, leverage, proporsi kepemilikan saham publik, reputasi KAP, dan likuiditas. 
Faktor yang Mempengaruhi Kelengkapan Pengungkapan Laporan Keuangan pada Perusahaan

Manufaktur yang Terdaftar di BEI

(Rofika dan Mustika Debby Apsari)

\section{METODE PENELITIAN}

\section{Populasi dan Sampel}

Populasi penelitian ini adalah perusahaan Manufaktur yang terdaftar di Bursa Efek Indonesia 2008. Teknik yang digunakan untuk penentuan sampel dalam penelitian ini adalah Purposive Sampling, artinya sampel dipilih dengan menetapkan kriteria-kriteria tertentu. Berdasarkan kriteria perusahaan yang terpilih menjadi sampel sebanyak 81 perusahaan.

\section{Jenis dan Sumber Data}

Data yang diperlukan dalam penelitian ini adalah Laporan Keuangan perusaahaan yang menjadi sample penelitian tahun 2008 dan indeks pengungkapan laporan keuangan.

Sumber data yang digunakan adalah data sekunder yang diperoleh dari Pusat Informasi Pasar Modal (PIPM) - BEI Pekanbaru, terbitan Indonesia Capital Market Directory (ICMD) yang dikeluarkan oleh Institute for Economic and Financial Research yaitu berupa data laporan keuangan, dan dapat di akses melalui http://idx.co.id. Serta indeks pengungkapan laporan keuangan yang diperoleh dari lampiran keputusan Bapepam No SE/PM/2002 yaitu penyajian pemahaman pengungkapan laporan keuangan emiten atau perusahaan publik industri manufaktur (http://www.bapepam.go.id).

\section{Variabel Penelitian}

Basis perusahaan (X1)

Basis perusahaan diukur dengan menggunakan variabel dummy, yaitu diberi skor 1 (satu) bila perusahaan berbasis asing dan diberi skor 0 (nol) bila berbasis domestik.

Ukuran Perusahaan (X2)

Ukuran perusahaan diukur dengan menggunakan total aktiva dari perusahaan sampel.

$$
\text { Size Perusahan }=\operatorname{Ln}(\text { Total Asset })
$$

Profitabilitas (X3)

Variabel profitabilitas diukur dengan membagi antara earnings after tax (EAT) dengan total asset.

$$
R O A=\frac{E A T}{\text { Total Asset }}
$$

Rasio Leverage (X4)

Penelitian ini menggunakan Debt to Total Asset Ratio perusahaan yang dijadikan sampel diukur dengan membagi total hutang dengan total aktiva.

$$
\text { Debt Ratio }=\frac{\text { Total Hutang }}{\text { Total Aktiva }}
$$

Proporsi Kepemilikan Saham Publik (X5) 
Vol 6, No 2, Oktober 2011: 99 - 109

Proporsi kepemilikan saham publik dalam penelitian ini diukur dengan membagi antara jumlah saham yang dimiliki masyarakat dengan total saham perusahaan.

$$
\text { PUBC }=\frac{\text { Saham yang dimiliki masyarakat }}{\text { Total saham perusahaan }}
$$

Reputasi Kantor Akuntan Publik (KAP) (X6)

Reputasi KAP diukur dengan menggunakan variabel dummy. Variabel ini diukur dengan cara memberikan nilai 1 untuk laporan keuangan yang diaudit oleh KAP yang berafiliasi dengan KAP the big four dan memberikan nilai 0 untuk laporan keuangan yang diaudit oleh KAP yang tidak berafiliasi dengan KAP the big four.

Likuiditas (X7)

Penelitian ini menggunakan rasio lancar (current rasio) perusahaan yang diukur dengan membagi aktiva lancar terhadap kewajiban lancar (Syamsuddin, 2007:68).

Kelengkapan Pengungkapan Laporan Keuangan (Y)

Variabel dependen dalam penelitian ini adalah kelengkapan pengungkapan laporan keuangan tahun 2008. Variabel ini mengukur berapa banyak butir pengungkapan laporan keuangan yang material diungkap oleh perusahaan. Untuk mengukur kelengkapan pengungkapan dapat dinyatakan dalam bentuk Indeks Kelengkapan Pengungkapan (indeks disclosure). Indeks disclosure merupakan hasil pembagian antara skor pengungkapan yang telah diraih dengan total nilai maksimum yang dapat diraih (Subiyantoro dalam Irawan, 2006).

Dalam melakukan perhitungan indeks, di mana item-item informasi yang digunakan mencakup mandatory dan voluntary. Item yang dipilih dalam indeks pengungkapan ini sebanyak 128 item.

$$
\text { Indeks }=\frac{\mathrm{n}}{\mathrm{k}}
$$

Keterangan :

$$
\begin{aligned}
& \mathrm{n}=\text { Jumlah item pengungkapan yang diraih } \\
& \mathrm{k}=\text { Jumlah maksimal item pengungkapan yang dapat diraih }
\end{aligned}
$$

Untuk pengujian hipotesis digunakan persamaan regresi berganda dengan formula sebagai berikut:

$$
\text { ID }=\alpha+\beta_{1} \text { BSS }+\beta_{2} \text { SIZE }+\beta_{3} \text { ROA }+\beta_{4} \text { LEV }+\beta_{5} \text { PUBC }+\beta_{6} \text { KAP }+\beta_{7} \text { CURRAT }+e
$$

Keterangan :

$$
\begin{array}{ll}
I D & =\text { Indeks Pengungkapan atau Disclosure } \\
\alpha & =\text { Konstanta } \\
\beta_{1}-\beta_{7} & =\text { Koefisien regres }
\end{array}
$$


Faktor yang Mempengaruhi Kelengkapan Pengungkapan Laporan Keuangan pada Perusahaan

$\begin{array}{ll}\text { BSS } & =\text { Basis Perusahaan } \\ \text { SIZE } & =\text { Size Perusahaan } \\ R O A & =\text { Profitabilitas } \\ \text { LEV } & =\text { Leverage } \\ \text { PUBC } & =\text { Porsi Kepemilikan Saham Publik } \\ \text { KAP } & =\text { Reputasi Kantor Akuntan Publik } \\ \text { CURRAT } & =\text { Likuiditas } \\ e & =\text { Koefisien error }\end{array}$

\section{HASIL DAN PEMBAHASAN}

Untuk mengetahui apakah model pengujian hipotesis dilakukan dengan tepat, dapat diketahui dengan membandingkan $p$-value dengan alpha. Dalam penelitian ini digunakan $\alpha=$ $5 \%$ yang artinya kemungkinan kesalahan hanya boleh kecil atau sama dengan $5 \%$. Jika $p$ value $<0,05$ maka dapat disimpulkan hipotesis diterima yang artinya variabel independen mempengaruhi variabel dependen.

Hasil regresi berganda untuk model regresi penelitian dapat dilihat pada Tabel 1 berikut:

Tabel 1. Hasil Analisis Regresi Berganda

\begin{tabular}{l|r|r|r|c}
\hline Variabel & $\begin{array}{c}\text { Koefisien } \\
\text { (Beta) }\end{array}$ & t.Hitung & Sig. $(<0,05)$ & Keterangan \\
\hline (Constant) & -.139 & -.858 & .394 & Tidak Signifikan \\
Basis & -.014 & -.747 & .458 & Signifikan \\
Ukuran & .045 & 3.410 & .001 & Tidak Signifikan \\
ROA & .116 & 1.105 & .273 & Signifikan \\
LEV & .120 & 2.393 & .019 & Tidak Signifikan \\
PUBC & .000 & .225 & .823 & Tidak Signifikan \\
KAP & -.019 & -1.088 & .280 & Tidak Signifikan \\
CURRAT & .004 & .640 & .524 & \\
\hline
\end{tabular}

$R^{2}=0,222 \quad$ Adj $R^{2}=0,148 \quad F=2,984 \quad$ Sig. $F=0,008$

$\mathrm{T}$ tabel $=1,980 \quad \mathrm{~F}$ tabel $=2,14$

Sumber : Hasil Pengolahan Data SPSS

Dari Tabel 1 dapat dilihat variabel basis perusahaan memiliki p-value 0,458 dengan $\alpha=0,05$, hal ini berarti $p$-value $>$ alpha, maka $\mathrm{H}_{1}$ ditolak. Dengan demikian, dapat disimpulkan bahwa basis perusahaan tidak berpengaruh signifikan terhadap kelengkapan pengungkapan laporan keuangan.

Penolakan hipotesis pertama ini sejalan dengan penelitian yang dilakukan oleh Amalia (2005) dan Marulitua (2009) yang menyatakan bahwa basis perusahaan tidak berpengaruh pada tingkat pengungkapan sukarela. Dan hasil penelitian ini juga tidak mendukung teori yang dikemukakan oleh Susanto (1992) dalam Amalia (2005), bahwa 
Vol 6, No 2, Oktober 2011: 99 - 109

perusahaan yang berafiliasi dengan perusahaan asing (PMA) akan melakukan pengungkapan yang lebih luas dibanding dengan perusahaan yang berafiliasi dengan perusahaan domestik (PMDN). Hal tersebut kemungkinan terjadi karena penelitian yang dilakukan oleh Susanto (1992) berfokus pada semua pengungkapan informasi dalam laporan keuangan termasuk pengungkapan informasi sukarela pada laporan tahunan, sedangkan penelitian ini berfokus hanya pada pengungkapan wajib.

Veriabel ukuran perusahaan memiliki nilai $p$-value sebesar 0,001 . Hal ini berarti $p$ value < alpha, maka $\mathrm{H}_{2}$ diterima. Dengan demikian, dapat disimpulkan bahwa ukuran perusahaan berpengaruh signifikan terhadap kelengkapan pengungkapan laporan keuangan.

Penerimaan hipotesis ini disebabkan karena perusahaan besar pada umumnya mempunyai beragam produk dan beroperasi di berbagai wilayah termasuk luar Negeri. Sehingga perusahaan besar lebih mungkin merekrut karyawan dengan keterampilan tinggi (high skill) yang di perlukan untuk menerapkan sistem pelaporan manajemen yang canggih sehingga dapat mengemukakan informasi yang lebih lengkap. Hasil penelitian ini sesuai dengan penelitian Hertanti (2005), Irawan (2006), dan Almilia dan Retrinasari (2007).

Variabel profitabilitas memiliki nilai $p$-value sebesar 0,273 . Hal ini berarti $p$-value > alpha, maka $\mathrm{H}_{3}$ ditolak. Dapat disimpulkan bahwa profitabilitas tidak berpengaruh signifikan terhadap kelengkapan pengungkapan laporan keuangan.

Hasil penolakan hipotesis ini disebabkan rendahnya profitabilitas menunjukkan tidak efektifnya aktivitas yang dijalankan perusahaan sehingga perusahaan enggan mengungkapkan laporan keuangannya secara berlebih karena kekhawatiran akan kehilangan para investornya. Jika perusahaan mengungkapkan laporan kuangan secara berlebih maka perusahaan pesaing akan lebih mudah mengetahui strategi yang dijalankan perusahaan sehingga dapat melemahkan posisi keuangan dalam persaingan. Penelitian ini sejalan dengan penelitian Hertanti (2005), Irawan (2006) serta Meiyusti (2009).

Variabel leverage memiliki nilai $p$-value sebesar 0,019 . Hal ini berarti $p$-value $<$ alpha, maka $\mathrm{H}_{4}$ diterima. Leverage memiliki pengaruh yang signifikan terhadap kelengkapan pengungkapan laporan keuangan. Pada perekonomian yang baik, perusahaan dengan leverage yang tinggi akan lebih banyak mempunyai kesempatan untuk memperoleh laba yang tinggi. Para pemegang saham lebih menginginkan perusahaan dengan leverage yang tinggi karena akan meningkatkan laba yang diharapkan tanpa mengurangi pengendaliannya tehadap perusahaan. Oleh karena itu, perusahaan dituntut untuk lebih mengungkapkan butir-butir laporan keuangan secara lengkap untuk tetap mempertahankan kepercayaan para krediturnya.Hasil penelitian ini sejalan dengan penelitian Simanjuntak dan Widyastuti (2004), Hertanti (2005).

Variabel proporsi pemilikan saham oleh publik memiliki nilai $p$-value sebesar 0,823 . Hal ini berarti $p$-value > alpha, maka $\mathrm{H}_{5}$ ditolak. Proporsi kepemilikan saham publik tidak 106 
berpengaruh signifikan terhadap kelengkapan pengungkapan laporan keuangan. Hal ini dapat disebabkan karena investor publik umumnya investor kecil, sehingga tidak dapat banyak mempengaruhi atau tawar-menawar yang seimbang dengan manajemen sehingga tidak ada perbedaan besarnya tuntutan informasi antara situasi jika proporsi kepemilikan saham publik yang besar. Selain itu investor yang ada di lapangan lebih mengandalkan alat analisis yang besifat fundamental sehingga kelengkapan pengungkapan laporan keuangan tidak berpengaruh terhadap proporsi kepemilikan saham publik. Hasil ini sesuai dengan penelitian Yuliansyah (2007)

Variabel reputasi KAP memiliki nilai p-value sebesar 0,280. p-value > alpha, $\mathrm{H}_{6}$ ditolak. Berarti reputasi KAP tidak berpengaruh signifikan terhadap kelengkapan pengungkapan laporan keuangan. Hal ini disebabkan kasus di Indonesia meskipun perusahaan diaudit oleh KAP big 4 dengan tingkat kredibilitas tinggi, hal ini tidak dapat mempengaruhi perusahaan untuk lebih transparan dalam mengungkapkan informasi pada laporan keuangan. Ruang lingkup auditor dalam hal ini hanya bertindak sebagai advisor dan memberi opini atas penyajian laporan keuangan yang bersifat wajib (mandatory disclosure). Hasi penelitian ini sejalan dengan penelitian yang dilakukan oleh Dwiningsih (2005).

Llikuiditas memiliki nilai $p$-value sebesar 0,524. Ini berarti $p$-value $>$ alpha, maka $\mathrm{H}_{7}$ ditolak. Berarti likuiditas tidak berpengaruh signifikan terhadap kelengkapan pengungkapan laporan keuangan. Hal ini mungkin juga disebabkan karena manajemen perusahaan di Indonesia menggunakan media (mekanisme) lain diluar pengungkapan wajib dalam laporan tahunan untuk menjelaskan perbedaan kepentingan (conflict of interest) antara pemegang saham, kreditur dan manajer perusahaan. Hasil penelitian ini sejalan dengan penelitian Irawan (2006), Handoko (2007).

\section{SIMPULAN}

Berdasarkan hasil pengujian regresi berganda mengenai faktor-faktor tang mempengaruhi kelengkapan pengungkapan laporan keuang diperoleh simpulan dari tujuh variabel independen ukuran perusahaan dan leverage yang memiliki pengaruh yang signifikan terhadap kelengkapan pengungkapan laporan keuangan perusahaan Sedangkan lima variabel independen lainnya yaitu basis perusahaan, profitabilitas, proporsi kepemilikan saham oleh publik, reputase KAP dan likuiditas tidak memiliki pengaruh signifikan terhadap kelengkapan pengungkapan laporan keuangan perusahaan.

Rekomendasi untuk penelitian berikutnya adalah, karena Indeks pengungkapan yang digunakan dalam penelitian ini ditentukan atas dasar penilaian terhadap ungkapan yang dibuat oleh peneliti setelah membaca dan mengamati sehingga masih bersifat subjektif dan kemungkinan terjadi salah interpretasi. Oleh karena itu, untuk menghindari adanya 
Vol 6, No 2, Oktober 2011: 99 - 109

subyektifitas indeks pengungkapan serta salah interpretasi, maka perlu melibatkan orang lain yang ahli dalam menilai indeks pengungkapan.

\section{DAFTAR PUSTAKA}

Aida Noviani., 2006. Analisis Pengungkapan Laporan Tahunan pada Perusahaan Manufaktur yang Terdaftar di BEJ, Skripsi, Fakultas Ekonomi Universitas Islam Indonesia, Yogyakarta.

Bapepam., 2002. Lampiran Keputusan Ketua BAPEPAM No. SE-02/PM/2002, Himpunan Peraturan Pasar Modal Indonesia, Jakarta.

Bambang Irawan., 2006. Faktor-faktor yang Mempengaruhi Kelengkapan Pengungkapan Laporan Keuangan pada Perusahaan Manufaktur yang Terdaftar di BEJ, Skripsi, Fakultas Ekonomi Universitas Islam Indonesia,. Yogyakarta.

Dessy Amalia., 2005. Faktor-Faktor yang Mempengaruhi Luas Pengungkapan Sukarela (Voluntary Disclosure) pada Laporan Tahunan Perusahaan yang Tercatat di BEJ, Jurnal Akuntansi Pemerintah, Vol, 1. No. 2, Fakultas Ekonomi UGM, Yogyakarta.

Dewi Hertanti., 2005. Pengaruh Faktor-Faktor Fundamental Terhadap Kelengkapan pengungkapan Laporan Keuangan Perusahaan Manufaktur yang Terdaftar di Bursa Efek Jakarta, Skripsi, Fakultas IImu Sosial, Jurusan Akuntansi, Universitas Negeri Semarang.

Dian Meiyusti., 2009. Pengaruh Ukuran Perusahaan, Profitabilitas, Leverage, Proporsi Kepemilikan Saham Publik, Reputasi Kantor Akuntan Publik dan Likuiditas terhadap Tingkat Pengungkapan Laporan Keuangan Tahunan pada Perusahaan Manufaktur yang Terdaftar di BEJ, Skripsi, Fakultas Ekonomi Universitas Riau.

Farichah., 2009. Analisis Hubungan Antara Karakteristik dan Kualitas Pengungkapan pada Laporan Keuangan Perusahaan Indonesia, Jurnal Akuntansi dan Keuangan, Vol. 14 No. 2, Fakultas Ekonomi Universitas Lampung.

Handi Handoko., 2006. Pengaruh Size Perusahaan, Likuiditas, Solvabilitas, Lamanya Listing, dan Proporsi Kepemilikan Publik Terhadap level of Disclosure pada perusahaan Manufaktur yang Listing di Bursa Efek Jakarta, Skripsi, Fakultas Ekonomi Universitas Riau.

IDX. 2009. Indonesian Capital Market Directory (ICMD), Bapepam, Jakarta.

Luciana Spica Almilia dan Ikka Retrinasari., 2007. Analisis Pengaruh Karakteristik Perusahaan Terhadap Kelengkapan Pengungkapan Dalam Laporan Tahunan Perusahaan Manufaktur yang Tedaftar di BEJ, Jurnal Akuntansi Universitas Trisakti, April 2007.

Lukman Syamsuddin., 2007. Manajemen Keuangan Perusahaan, Edisi Baru-9. PT. Raja Grafindo Persada, Jakarta.

Marulitua Johannes., 2009. Pengaruh Size Perusahaan, Profitabilitas, Solvabilitas, Proporsi Kepemilikan Saham oleh Publik dan Basis Perusahaan Terhadap Luas Voluntary Disclosure pada Perusahaan Manufaktur yang Terdaftar di BEJ, Skripsi, Fakultas Ekonomi Universitas Riau.

Rhia Dwiningsih., 2009. Pengaruh Struktur Kepemilikan, Ukuran Perusahaan, Ukuran Kas, dan Komisaris Independen Terhadap Transparansi Informasi, Skripsi, S1 Fakultas Ekonomi Universitas Riau.

Yuliansyah dan Yenny Megawati, 2007. Pengaruh Karakteristik Perusahaan Terhadap Tingkat Keluasan Pengungkapan Laporan Keuangan pada Sektor Industri Barang Konsumsi di Bursa Efek Jakarta, Jurnal Akuntansi dan Keuangan, Vol. 12 No. 1, Bandarlampung. 
Faktor yang Mempengaruhi Kelengkapan Pengungkapan Laporan Keuangan pada Perusahaan

Manufaktur yang Terdaftar di BEI

(Rofika dan Mustika Debby Apsari)

http//: www.bapepam.go.id. Diakses pada Oktober 2010.

http//: www.idx.co. Diakses pada Oktober 2010. 